\title{
WORK IN PROGRESS
}

"Work in progress" is a forum for students and university graduates who wish to present the results of their research.

\section{The Development of the Protagonist in Rudolfo Anaya's Chicano Bildungsroman Bless Me, Ultima}

\begin{abstract}
. he main aim of this article is to examine the psychological and emotional development of the protagonist of Rudolfo Anaya's Bless Me, Ultima, a book which is perceived as a prime example of Chicano Bildungsroman. First, I concentrate on providing brief theory about the sub-genre of Bildungsroman and on Chicano literature to situate Anaya's novel within these contexts. A considerable part of the article is devoted to the analysis of the protagonist's family background and school environment, which signify the influences of Mexican and American culture in his life. Finally, the motifs of war, violence and death are discussed as significant factors contributing to the protagonist's coming of age.
\end{abstract}

Keywords: Bildungsroman; Chicano literature; Rudolfo Anaya; Bless Me; Ultima.

A Bildungsroman can be understood as a coming of age story, in which we get to know how certain incidents and particular environments influence an individual. The sub-genre itself focuses mainly on the psychological exploration of human reactions following disturbing experiences. At times it emphasizes the psychological turbulence of one person, other times it draws readers' attention to the visible problems of a bigger group. But it is always about the development of a personality, identity, and a social self. The main aim of this article is to examine the psychological and emotional development of the main protagonist of Rudolfo Anaya's Bless Me, Ultima. 


\section{Bildungsroman and Chicano literature}

One of the most general definitions of the Bildungsroman states that it is "a generic term for a novel that focuses on the psychological and social development of its main character" (Redfield 2006: 191). It is, therefore, a novel in which readers follow the protagonist through his or her adolescence. Kelsey Bennett (2014: 2) claims that spiritual traditions were the basis for creating the Bildungsroman as it is a sub-genre closely connected with individual experience and self-formation. She notices that in Luther's translation of the Bible, he uses the word Bild to express God's image and that "the responsibility for spiritual formation shifted directly to the individual, whose primary source of external inspiration and guidance became the Bible itself" (Bennet 2014: 4). According to this view, Bildungsroman was created as an answer to religious self-searching and only later did it gain its meaning of a novel about a more general development.

The sub-genre enjoyed a particular popularity in $19^{\text {th }}$ century, when Europe "witnessed the apex both of historicism and of nationalism" (Boes 2008: 17). The new events in the lives of people made them less secure and provoked emotions that were deeply hidden before. Therefore, people felt a need of expressing those emotions and sharing their experiences through writing Bildungsroman. Some of the greatest Bildungsroman novels of that century are, unquestionably, Charles Dickens's David Copperfield (1850), Gustave Flaubert's Sentimental Education (1869), or Mark Twain's The Adventures of Huckleberry Finn (1884).

One of the most typical elements of the Bildungsroman is the presence of a mentor. It is the mentor who teaches the young protagonist and directs his or her development into the right direction. This is usually an elderly, experienced person, whose world outlook appeals to the character at this particular stage of life (Garasym 2012: 187). Some attention should be also devoted to the Bildungsroman's narrator. Tetyana Garasym (2012: 186) notices that such stories are predominantly told from the perspective of an adult and mature protagonist who has already found his place in life. In consequence, the image of the formation process relies on references to the past. All, or almost all, of the events taking place in the novel are the memories of the narrator.

Significantly, Bildungsroman is about finding and building a national identity. A substantial aim of a coming of age novel is to show how young people find their way to become citizens. Sometimes the protagonist can be described as the representative of a whole nation. This often creates some kind of an ironic situation as the protagonists become mature in an immature nation (Latinez 2014: 6). This happens especially in the context of Latin America, where we can still observe some influences from Native American culture. The characters of the stories frequently go beyond the framework and become more aware and developed than the rest of the society. They can later make use of their maturity and fight for what they have discovered is right and therefore draw people into changing the common view. According to Stella Bolaki (2011: 10-11), this subgenre "has an enduring power" and "offers an appropriate site for the negotiation of a number of enduring and contentious tensions in ethnic American writing". It is not only about finding oneself but also about exploring social problems. 
One particular type is the Chicano Bildungsroman, focusing on Mexican-American society. Its main characteristic is that it combines the elements of both Mexican and American cultures. As we read in the article written by Eysturoy and Gurpegui (1990: 48-82), the history of MexicanAmericans begins in the year 1848 and the roots of Chicano literature lie in this historical context. 1848 was the year when the treaty of Guadalupe Hildago was signed and the war between Mexico and the United States ended. The appearance of Chicano literature may come from the fact that many Mexican-Americans find the border between both countries "an artificial one" (Eysturoy, Gurpegui 1990: 48). On an everyday basis the minority lives in an environment exposing them to the combination of both cultures.

The beginnings of Chicano short fiction are indisputably connected with the oral tradition of storytelling and with traditional cuentos (stories). As a part of folk speech, proverbs and traditional sayings can be perceived as the "voice of collected wisdom or proven authority" (Ortega 2012: 548) and a significant element of indigenous Mexican culture. It provides advice in an inoffensive way and refers to the experience of past generations. Thus, through the folk tales we can learn a lot about the culture and history of Chicanos. Another characteristic of Chicano/a literature is the inclusion of violence. In his article "Chicano Studies and the Need to Not Know" Rodriguez (2010: 180) observes that what is often included in Chicano/a works is the figure with his or her pistol; the tendency to employ such figures "emerges from a desire to rectify a long history of racism, patriarchy, economic exploitation, and cultural neglect and derision". Although it is mentioned that such symbolic characters with pistols appear as a result of the Chicano Movement of the 1960s, they are still present in today's novels. Additionally, it is also a common phenomenon that Chicano/a writers prefer to employ a strategy of code switching in which predominantly English texts are infused with Spanish words (Schmidt 2011: 40). This combination shows that the authors refuse to be defined by one culture and that they do not want to "fall into one neat and distinct category" (Schmidt 2011: 40), hoping to somehow make people aware of the complexity of Chicano/a identity.

Chicano literature, especially works of the last three decades, is "the culmination of long-standing sentiments and traditions" (Eysturoy, Gurpegui 1990: 49). The mixture of cultures and the combination of motifs undoubtedly make Chicano coming of age novels exceptionally intriguing. The novel of formation located in a place where different heritages collide allows readers to step into an extraordinary world, known only by a few people.

\section{Family background and Mexican culture}

At the beginning of Bless Me, Ultima, Tony is a six-year-old boy and an innocent character. In spite of his young age, he seems to be quite precocious. It is right to say that as a boy Antonio is "quite thoughtful and serious, often prone to moral questioning" (Sharma 2013). He spends his free time helping with the farm and definitely does not concern himself with his sisters' pastimes. Although they are older, it is he who seems to be more grown-up. Despite the fact that in many characteristics the protagonist differs from his peers and seems to be more mature, he is lost. Tony, "the inquisitor" (Anaya 1972: 33), is a boy with many questions to ask, but not all of them are directly answered. Al- 
though he learns through the guidance and advice given by his parents and a mentor, Ultima, their words gain in meaning only with time and the experiences he has to go through himself.

As readers, we are the witnesses of how Tony's identity is built by the environment in which he is growing up. It is believed that the hallmark characteristics of traditional Mexican family values are supportive family bonds and the strong expectations regarding family loyalty (Cauce, Domenech-Rodríguez 2002: 3-25). As Saracho and Martínez-Hancock (2005: 212) notice, "traditional Mexican-American families are those who still maintain values of typical communities that are rural, located close to the Mexican border, and situated where most of the population is Mexican American". Undoubtedly, all of these features could serve as a description of Tony's family. However, the family values associated with Mexican culture are shown here as influences that are more complicated and less unified than we stereotypically believe.

What is surely important while considering Antonio's process of maturing is his surname and its origin, which signifies his family background. The full name of the protagonist is Antonio Juan Márez y Luna, which indicates that Tony comes from two totally different types of Mexican society. As Theresa Kanoza (1999: 159) notices, "Rudolfo Anaya presents a world of opposites in the New Mexican village of Guadalupe. The parents of the young protagonist Antonio have strikingly different temperaments, as dissimilar to each other as the backgrounds from which they hail". The first world is represented by the father, a vaquero (cowboy) with "a calling as ancient as the coming of the Spaniard to Nuevo Méjico" (Anaya 1972: 2). The men of the llano (plains) in Bless Me, Ultima are described as "men of the sun" (Anaya 1972: 27). They are loud and wild, "like the ocean from which they take their name, and the species of the llano that have become their home" (Anaya 1972: 41). People from Las Pasturas are also witty and there is always a song in their excited talks. As Tony notices, they were "like the wind, and the fragrances they carried on their clothing shifted as the wind shifted" (Anaya 1972: 125). It is the wind and their blood that sets vaqueros wandering and enjoying life to the fullest. In contrast, Maria, Antonio's mother, is not defined as a woman of the llano. She is a daughter of a farmer and the Lunas' origins are strongly connected with the moon: "They planted their crops and cared for their animals according to the cycles of the moon. They lived their lives, sang their songs, and died under the changing moon. The moon was their goddess" (Anaya 1972: 90). The mother's family is also said to be strange and quiet, "for only a quiet man can learn the secrets of the earth that are necessary for planting" (Anaya 1972: 41). What they do is speak to the earth with their hands and use their words mostly to communicate with growing plants (Anaya 1972: 46).

Interestingly enough, the protagonist, who is also the narrator, makes such a point: "Why two people as opposite as my father and my mother had married I do not know. Their blood and their ways had kept them at odds, and yet for all this, we were happy" (Anaya 1972: 29). The differences in his parent's origins result in distinct expectations of what their son should be like. Gabriel expects his son to make a fine vaquero. His dream is "to gather his sons around him and move westward to the land of the setting sun, to the vineyards of California" (Anaya 1972: 14). The father waits for his children as he strongly believes that they will do what he expects. As it is the way of 
life Gabriel knows best, he wishes that someday Tony will fulfill his dreams of living in the llano. However, the expectations of the mother differ. Once in the past "she wanted to buy along the river where the land was fertile and there was water for the plants and trees" (Anaya 1972: 24), but it was Gabriel who decided that they would settle close to his llano. The mother dislikes the people occupying this place and perceives them as thieves and worthless drunks starting fights. She also complains that they move like gypsies and drag their families around the country like vagabonds (Anaya 1972: 9). Although Maria finds the village of Las Pasturas beautiful, she does not accept its people and, as the protagonist observes, she does not follow their thinking: "She did not understand their tragedy, their search for the freedom that was now forever gone. My mother had lived in the llano many years when she married my father, but the valley and the river were too ingrained in her for her to change" (Anaya 1972: 126). The fact that Maria has only a few friends in the town shows how difficult for her is to live in the place Gabriel chose.

All these apparently incompatible components, inherited from the parents, combine in the protagonist, who observes: "The four directions of the llano met in me, and the white sun shone on my soul. The granules of sand at my feet and the sun and sky above me seemed to dissolve into one strange, complete being" (Anaya 1972: 12). Therefore, we can see that the protagonist is torn between the elements of his origin; lost as much as his parents are. Especially the father, whose raging about the town, old age, lost dreams and war seem to show the forcefulness of his frustration. Gabriel is displaced psychologically and blames everything that surrounds him for his disempowerment (Black 2000: 151-152):

He cursed the weak-willed men of the town who did not understand the freedom a man of the llano must have, and he cursed the war for taking his sons away. And if there was very much anger in him he cursed my mother because she was the daughter of farmers, and it was she who kept him to one piece of land. (Anaya 1972: 28)

Antonio's parents represent two completely opposite perspectives and they are of different heritage. It is the conflict between their origins that influences Antonio, who needs to find his own identity. At the beginning of the novel, the protagonist does not seem to know yet whose steps to follow: "Now we have come to live near the river, and yet near the llano. I love them both, and yet I am of neither. I wonder which life I will choose?" (Anaya 1972: 41). The boy seeks answers and one of the most significant questions he asks is about who he really is: whether he is more a Márez or a Luna.

It is worth noticing that the Mexicanity shown in the novel is not a univocal category. As Neal Finer (1979: 6) noticed, "the rich diversity of Mexico's contemporary culture is the product of several cultures which have blended" - influences from the Indian cultures of the pre-Cortesian period, the Spanish-Moorish-French cultures of the Colonial period, and the nationalist and internationalist cultures of the twentieth century are still present in contemporary Mexico. The clash of various traditions and beliefs can serve, therefore, as a reason for the differences between Gabriel and Maria's origins. Another type of diversity appears when we consider the different ideas of 
manhood incorporated into the novel. Antonio is strongly influenced not only by his father but also by his uncles, who are completely distinct from what Gabriel represents.

Although at first it is impossible for him to define his identity, at the end of the novel Tony surprises his uncle Pedro with the ascertainment that he is Márez first and then he is Luna. Although the boy is not yet aware of the reason for this statement and answers instinctively, we can acknowledge that he does not want to be perceived strictly as a Luna. From the beginning we know that someday he will "return and see the little village where the train stopped for water, where the grass was as high and green as the waves of the ocean, where the men rode horses and they laughed and cried at births, weddings, dances, and wakes" (Anaya 1972: 32). He remembers very well that the place of his birth is Las Pasturas and notices that the only thing he needs to do in order to return to the land is to follow the railroad tracks. His father said that the llano was his school, his teacher and his first love at the same time (Anaya 1972: 54). Gabriel is touched whenever he thinks about the plains and it seems that they are nearly of the same significance for Tony. One of Tony's dreams brings the thought: "I recognized the village of Las Pasturas and my heart grew happy" (Anaya 1972: 5). It is, therefore, a place which touches Antonio and makes him feel closer to his heritage. He has the village in his mind and dreams about visiting it in the future.

Further in the novel we discover that Tony's uncles are pleased with his input into the work on the farm. Consequently, they ensure him that if one day he chooses to follow in their steps, the land of his mother will become his property. Although in the novel we are not to find the final decision, Tony sincerely appreciates the time he spent with his mother's brothers:

I learned much from those men who were as dark and quiet as the earth of the valley, and what I learned made me stronger inside. I knew that the future was uncertain and I did not yet know if I could follow in their footsteps and till the earth forever, but I did know that if I chose that life it would be good (Anaya 1972: 251).

In the novel, the time Tony spends on the farm is concluded as the last summer when he was truly a child. It seems, therefore, that as he can appreciate being both a Marez and a Luna, he begins to feel more secure. He is too young to choose yet, but he knows that there is something positive ahead of him. This safety makes him feel better about living in the world of differences that surrounds him and it gives him certain stability. Consequently, it can also serve as a sign of the character's growth into maturity.

While raising the subject of Antonio's process of development, we cannot overlook the contribution of an eponymous character, Ultima. She is the one to school Antonio in the history and culture of his ancestors, and hence help the protagonist find his deep origins. She is the next, after Antonio's father, to remind him about the llano: "When she came the beauty of the llano unfolded before my eyes, and the gurgling waters of the river sang to the hum of the turning earth" (Anaya 1972: 1). It is also she who makes Tony feel like a part of it. As we read in the introduction to the novel, Ultima's appearance in Bless me, Ultima causes that her grandson "opens his eyes" and that "the ordinary conflicts of childhood take on a deeper meaning" (Anaya 1999). At some point, Ultima seems to be even closer to Tony than Maria: 
Ultima and I continued to search for plants and roots in the hills. I felt more attached to Ultima than to my own mother. Ultima told me the stories and legends of my ancestors. From her I learned the glory and the tragedy of the history of my people, and I came to understand how that history stirred in my blood. (Anaya 1972: 123She is the one taking care of Tony's learning about the past. Ultima explains the historical and cultural foundations of Mexican beliefs, thus encouraging the protagonist to learn about each aspect of his heritage.

The general truths Ultima introduces make her an extremely significant character and a mentor. She is not only experienced but also wise. As a matter of fact, she loves to share her knowledge with Antonio although at times he seems to be too young to understand. Ultima is described as the one holding the secret of Antonio's destiny as she delivered the boy from his mother's womb. She is with him from the beginning of his life and even predicts that he will be a man of learning: "You remember, Grande, you offered him all the objects of life when he was just a baby, and what did he choose, the pen and the paper" (Anaya 1972: 54). As much as his mother symbolizes a dream and his father a rebellion, Ultima is the equivalent of spiritual wisdom and mysticism. Additionally, she makes such an impression on Tony that he often watches her and imitates her moves. She is the one that most significantly inspires the protagonist.

Tony's family and Mexican culture are the elements that strongly determine the changes in his personality. The uncertainty that is caused by the visible difference in his parents' origins makes the boy uneasy at the beginning of the novel. However, it evolves and even disappears as the story develops. The boy begins his search for identity with the difficult task of choosing whose steps to follow. At the end of the road, though, he is able to defend his origins and calmly consider the possibilities of his own future. All in all, the family and its origins make Antonio a unique and mature character despite his young age. As a Chicano Bildungsroman protagonist, Antonio lives in a world where various influences collide. Although the diversity between American and Mexican cultures may be more apparent to the readers, it is the tapestry of Mexican culture that is more widely described in Bless Me, Ultima. It is essential to notice that Antonio is a pure Mexican when it comes to his origins and only later in the story he begins to develop the American identity that he received as a result of his family's emigration.

\section{School and American culture}

The element that largely builds Antonio's Americanity in Bless Me, Ultima is the school he attends. In the novel, this institution is the first place where children are exposed to American culture: "All of the older people spoke only in Spanish, and I myself understood only Spanish. It was only after one went to school that one learned English" (Anaya 1972: 10). Interestingly enough, it is a wellknown fact that language is one of the most important elements of human identity and culture. As William Bright (1976: 2) notes, "language is assured a position as a branch of culture by its distinctively patterned nature, by its restriction to the human species, and above all because languages are learned, not transmitted genetically". Consequently, once a person begins to speak another language, he or she simultaneously learns a fragment of a new culture. At the beginning of the novel 
Tony is not able to speak English yet: "[Deborah] had been to school two years and spoke only English. She was teaching Theresa and half the time I didn't understand what they were saying" (Anaya 1972: 11). However, he quickly learns to use the English language once he becomes a schoolchild. As the protagonist obtains the ability to speak English, he also gets in touch with the American culture. Antonio has to open up to a different culture in order to communicate on an everyday basis.

An interesting fact is that in Bless Me, Ultima the school is described as an institution in which all teachers speak only English. Thus, Antonio's going to school is like throwing him in at the deep end. As Phillip Serrato (2012: 238) notices, Antonio "finds that stepping away from [home] and out into the world literally and figuratively takes him into strange, new territory that challenges him in different ways". Home is a safe place, thus the singular thought of leaving his mother results in Tony's reaction of sickness. Once the protagonist moves forward and actually enters the threshold of school, he does not feel any better. Antonio is lost within the society of his peers and feels like an outcast. The protagonist experiences an extreme dejection:

The pain and sadness seemed to spread to my soul, and I felt for the first time what the grown-ups call, la tristesa de la vida. I wanted to run away, to hide, to run and never come back, never see anyone again. But I knew that if I did I would shame my family name, that my mother's dream would crumble. I knew I had to grow up and be a man, but oh it was so very hard. (Anaya 1972: 59)

The difficulties Antonio encounters are caused by his Mexican heritage. Not only is he unable to use the language of others but he also consumes different dishes. Once the protagonist hears words he does not recognize and while he sees the lunch made out of bread and not tortilla, he feels powerlessness. Therefore, another integral part of culture appearing in the novel is cuisine. Culturally, food traditions unite people and play a large role in the building of a sense of distinctiveness (Edelstein 2010: IX). Through the differences in language and food, Tony cannot find his place in this unfamiliar and terrifying reality and, not surprisingly, begins to think about running away.

The Mexican and American cultures clash in this all new world, but the boy manages to deal with the situation. What he learns from his family is that he should never try cowardly to escape difficulties. As Tony decidedly rejects the thought of disappointing his mother, he decides to face the problem. This situation leads to a personal success as the boy finds a solution without the help of his family, to which he is so attached. The same school that was the place of Tony's heartbreaking sorrow becomes an area of achievement. The protagonist makes new friends who are, like him, different in language and custom. One of Tony's first serious experiences ends up favorably: "We struggled against the feeling of loneliness that gnawed at our souls and we overcame it; that feeling I never shared with anyone" (Anaya 1972: 59). The success mentioned is an element that directs Tony to his independence. He steps out from the familiar Mexican world and gains some autonomy from it. He becomes a member of the new culture without his nearest and dearest beside him, and thus becomes more self-reliant. What is more, he makes another step towards the discovery of his own identity. 
It is worth mentioning that Tony's inability to speak English quickly disappears despite the fact that Antonio's father is opposed to his son's Americanization: “They only learn to speak like Indians. Gosh, okay, what kind of words are those?" (Anaya 1972: 54). Gabriel, seems to perceive English as the language of Indians, which in this case could be interpreted as primitive and strange. He is not in favor of American culture and considers it inferior. The unfamiliarity and foreignness of American culture irritate and upset him. Reversely, Antonio's mother encourages the boy to learn English. As Maria strives to breed a man of learning, she intends her son to speak both Spanish and English. She is aware that in order to succeed, one has to be able to speak English:

She liked to hear me read the catechism in English, although she could not understand all I read, and I myself could not yet read with complete comprehension. Many of the old people did not accept the new language and refused to let their children speak it, but my mother believed that if I was to be successful as a priest I should know both languages, and so she encouraged me in both. (Anaya 1972: 179-180)

Maria's openness towards the new language encourages the protagonist to begin his educational journey. Driven by the desire to acknowledge the language, he begins to "unravel the mystery of the letters" (Anaya 1972: 64). As we read in the novel, he perceives letters and numbers as magic, knowledge as something mysterious and powerful that is worth mastering. Antonio is eager to learn the secrets of education and, more importantly, he succeeds. The teachers praise him and so eventually he passes two grades at once. He is aware of how education helps in adult life, so he works hard to develop himself in this area. As much as becoming educated is important to the protagonist, he never forgets his Mexican heritage. While attending the catechism he prefers to use his native language: "I prayed to myself, sharing my prayers with no one. Everyone else prayed in English" (Anaya 1972: 199). Although he is surrounded by American culture and understands its importance for achieving success, he tries to maintain, at the deepest spiritual level, what is connected with his Mexicanity.

School was also the place where Tony met the gang. Though with his sensibleness Tony differs from the members of the gang, he nevertheless manages to impress them with his courage, versatility, and unwillingness to judge. Despite the protagonist's awareness of the differences between him and his friends, he becomes a member of the gang: "They all gathered around me and asked me where I lived and about school. They were good friends, and that day I became a part of their gang" (Anaya 1972: 38). In Bless Me, Ultima the gang is described as a group of childish, badly behaved, violent and not very bright boys. They make "pissing contests", "burp in class", and constantly visit the principal's office (Anaya 1972: 75-76). The narrator himself is the one to notice that they are "the dumbest kids in school" and that "hell could freeze over but they would still come marching across the tracks, wrestling, kicking at each other, stomping into the classrooms where they fidgeted nervously all day and made things miserable for their teachers" (Anaya 1972: 151). Antonio, though, is a clever, intelligent, calm, and well behaved young man. 
The fact that the protagonist joins the gang can be easily explained, however. As we read in Gangs in the Schools by Burnett and Walz (1994: 3-4), gangs "often provide youth with a sense of family and acceptance otherwise lacking in their lives. In addition, gangs may form among groups of recent immigrants as a way of maintaining strong ethnic identity". Therefore, the principal reasons for Tony's joining the gang are the facts that he does not feel well in the school environment and that he is lost among his peers. He seeks friends of the same origins, among whom he would feel comfortable and accepted. Although for the obvious reason of his innocence, he seems to be the last person who would join a gang, he does. All in all, the visible contrast between Tony and the other group members allows us to see the maturity in his ability to mold in the society. The protagonist becomes friends with people who could easily change his character. Instead, he tolerantly learns that even the most ill-mannered boys can own and develop some positive traits. It is also significant to mention that the protagonist is able to become one of them without changing his noble traits.

The school environment, therefore, becomes a significant factor in Antonio's coming of age as it makes him realize his difference and discover the magic of education. It also becomes a place in which this Chicano Bildungsroman protagonist learns to cope with the problems on his own, begins to open up for the American culture, and finds the group in which he can preserve his ethnicity.

\section{The influence of war, violence and death}

Although World War II appears only in the background and is not experienced directly, its influence is easily visible in the development of the protagonist of Bless Me, Ultima. In the novel, the image of the society facing war is described as mourning: "Those years it seemed that the whole town was in mourning, and it was very sad on Sundays to see the rows of black-dressed women walking in procession to church" (Anaya 1972: 32). Many sons and husbands were lost; the families were grief-stricken. In Tony's family the situation was not much better due to the departure of three sons who went to fight in the war. Especially influenced by the war was Antonio's father. Sometimes Tony could even see his father cry over the war ruining his dream: "It was sad to see my father cry, but I understood it, because sometimes a man has to cry. Even if he is a man" (Anaya 1972: 15).

As soon as the protagonist's brothers comes back from the war, though, it becomes clear that the life before their leaving would never return. As Serrato (2012) observes, "the stress of the times finally becomes all too real for [Antonio] through the breakup of his family. First his brothers leave home to fight in the war. Then, although they physically return, they never really return to the family" (Serrato 2012: 234-235). Andrew, Eugene and León are already unrecognizable. Since the very arrival, it is impossible for them to come back to the life from before the war:

My brothers had spent the winter sleeping during the day and in town at night. They were like turgid animals who did things mechanically. I saw them only in the evening when they rose to clean up and eat. 
Then they were gone. I heard in whispers that they were wasting their service money in the back room of the Eight Ball Pool Hall. My mother worried about them almost as much as she had when they were at war, but she said nothing. (Anaya 1972: 65)

Further in the eighth chapter, Tony also notices that his brothers "were like lost men who went and came and said nothing" (Anaya 1972: 65). The war-sickness seemed to be dragging them down and sometimes at night León would even howl and cry, thereby resembling a wild animal.

Another situation, also involving post-traumatic stress, takes place just at the beginning of the novel. Once we read about the first murder Antonio witnesses, we can be sure that not even an adult could get past such a deed undisturbed. Antonio hears that due to the war-sickness Lupito killed the sheriff and the boy's curiosity leads him to witness the revenge of the local people. Although Tony is just a child, he is old enough to understand that what happened was a part of the adult life full of violence, anger and sadness. The murder makes Tony's soul sick as he cannot forget the cry of a tormented man. In the novel, war is a theme which opens Antonio's eyes and encourages the protagonist to contemplate on the morality: "Now the men on the bridge walked the earth with the terrible burden of dark mortal sin on their souls, and hell was the only reward" (Anaya 1972: 28). After all, the character acknowledges war as changing his brothers drastically, making his father cry and even causing a man to commit a murder. At such a young age, Tony becomes aware of the tragedy that a life can bring. In the world of childish innocence, he suddenly approaches one of the most tragic problems the humanity encounters. Therefore, it seems that in Tony's eyes, the war destroys human lives and is an element which makes his brother drift apart from the rest of the family.

Moreover, it is in particular one of the protagonist's brothers that serves him a lesson about life. Andrew's misdeeds lead Antonio to the disappointment, which is one of the most significant events in the story. At first Andrew is introduced as the character encouraging Tony and believing in him: "Someday you will beat him, Tony. Some day you will beat us all" (Anaya 1972: 75). But then his brother, whom he undoubtedly trusts, refuses to come with help to a family's friend. Not only does Andrew spend time in a brothel, but also refuses to leave a prostitute and does not react when Narciso asks for help. The consequences could not be more serious as Narciso gets murdered. The change touching the protagonist is visible just after his discovery in a brothel: "I wanted to hate Andrew for being with the bad women, but I could not. I only felt tired and older" (Anaya 1972: 165). The incident serves as another step towards the protagonist's loss of innocence, and his reaction - feeling "tired and older" - indicates a certain weariness, and even resignation. In a very short time, he observes and experiences many situations that a regular child is not even aware of, most of them leading to a disappointment - with his own brothers, with his neighbors, perhaps with humanity itself.

It comes as no surprise that at some point the atmosphere between Tony and Andrew becomes uneasy. The murder that comes after Andrew's lack of reaction becomes an insurmountable problem and Antonio sadly drifts apart from his brother. He begins to think that he has never actually got to know his brothers and contemplates Andrew's running away: "I wondered if I could ever re- 
ally know my brothers, or would they remain but phantoms of my dreams. And I wondered if the death of Narciso had anything to do with Andrew's decision to go" (Anaya 1972: 185). What may be a surprise is that Antonio remains silent and does not reveal that he knows about his brother's behavior. As we get to the point where the protagonist assures that he had not told anyone and that he never would, we witness Tony's extremely adult behavior. The boy bafflingly decides to keep a secret which could calumniate his brother. Not only does Tony show his maturity but also generosity. This experience is significant for Andrew as well as for his younger brother, who begins to feel and act like a man.

Violence is a major theme in the novel, therefore, I should recount only some selected situations that are retained in the protagonist's memory. Probably the most violent person Tony encounters is Tenorio Trementina, a creature of evil, anger and revenge. Throughout the novel he is just looking for an opportunity to revenge the loss of his daughter. It seems that the longer he waits, the more frustrated he becomes. The fight between Narciso and Tenorio is already much for Antonio. In the same chapter of the novel, though, he is not only to witness another murder but also to become a target himself: "I heard a low moan as Tenorio aimed his pistol at the head of Narciso. I screamed with fear and Tenorio spun around and saw me. He aimed the pistol at me and I heard the click of the firing pin. But there was no shot" (Anaya 1972: 169). This occurrence makes Antonio feel older and different. Not surprisingly, he begins to seek answers to why somebody as noble as Narciso had to die. Although Antonio is unable to find a reason, he decides to fight the evil:

Not even when he killed Narciso had I seen so much hate in Tenorio's face. I seemed too small to stand in the way of a man bent upon destruction with such fury, but I remembered that my father had stood up to him, and Narciso had stood up to him, and even Ultima had stood against this evil; and although I was trembling with fright I answered him, "No! I will not let you!" (Anaya 1972: 188)

Indisputably, the protagonist is becoming stronger. The violence he experiences works as an element initiating his courage. It is worth mentioning that Tony is the one to deal with the bilateral hatred as he also hears his father and Narciso talking about killing Tenorio. Therefore, the stigma of the events affects him twice as much.

Another significant event that changes Antonio's worldview is the death of his peer. Florence is introduced as a boy whose life has never been effortless. With the mother who died when the boy was three years old, the father who drunk himself to death and the sisters working as prostitutes, Florence already seems to be an adult. His rueful story initiates the feeling of pity. Both Florence and Antonio do not understand why there is so much anguish and unfairness in the world. Once again, the thoughts about good and evil appear in the protagonist's mind. The death, present in the lives of these young characters, makes them ask questions about the sense of existence and about God:

"So l ask myself," [Florence] continued, "how can God let this happen to a kid. I never asked to be born. But he gives me birth, a soul, and puts me here to punish me. Why? What did l ever do to Him to deserve this, huh?" 
For a moment I couldn't answer. The questions Florence had posed were the same questions I wanted answered. (Anaya 1972: 196)

As the two boys have different perspectives, they are not able to find an unambiguous answer. Unfortunately, Florence does not even get the time to seek response as he drowns. Tony is left alone without answers to the previously asked questions and becomes even more uncertain of how to seek any good in this unjust world. The memories of people dying frequently strike Tony in his dreams and encourage him to search for the sense of existence.

Although the deaths of Lupito, Narciso and Florence change the protagonist, it is the passing of Ultima that signifies the end of Tony's childhood: “That shot destroyed the quiet, moonlit peace of the mill, and it shattered my childhood into a thousand fragments that long ago stopped falling and are now dusty relics gathered in distant memories" (Anaya 1972: 258). Because of the fact that one serious image of adult life comes after another very quickly, Tony's psychological and emotional development proceeds at a fast pace. Only after he experiences things as harrowing as violence and death is he able to understand fully the feelings of profound sorrow and disenchantment. He no longer knows these terms in theory only, but can now define them himself. The emotions that appear once a person matures become present in Antonio's life. He changes from a naïve child into a young man who acknowledges the dark side of the world. Therefore, the profusion of violence Tony experiences influences him strongly. In Bless Me, Ultima, we are not to read about a gleesome boy who grows in a trouble-free environment. Instead, we discover the life of a boy who is exposed to the adult life to such an extent that he himself becomes an adult. Although in his dreams the boy complains about the amount of brutality he has to get through, he finally begins to see its importance: "Why must I be witness to so much violence! I cried in fear and protest. The germ of creation lies in violence, a voice answered" (Anaya 1972: 243). It is the experience of death that initiates and ends his coming of age.

It is also worth mentioning that, as it was pointed out at the beginning of the article, Bildungsroman is focused on presenting events from the perspective of a mature person. In this case, we can also describe Bless Me, Ultima as the memoir of the protagonist. In his novel, Anaya wishes to present the part of the protagonist's life that is the most significant to Antonio's adult self and describe the events that are, often unwillingly, retained in his memory. As an experienced man, the narrator evokes the memories from a period which he spent with one of the most important people in his life, Ultima. The narration is presented from the perspective of a grown man who willingly describes his past, rarely focusing on the present. However, with every mention of the here and now, the readers are assured about the influence of the incidents and people on the protagonist's adulthood: "Many years later, long after Ultima was gone and I had grown to be a man, I would awaken sometimes at night and think I caught a scent of her fragrance in the cool-night breeze" (Anaya 1972: 13). Recollecting the past in Bless Me, Ultima can be described as sentimental and detailed at the same time. Anaya goes very deeply into the protagonist thoughts, even trying to recall his youth's dreams. This type of first person narrative, typical for Bildungsroman, 
undoubtedly creates some kind of intimacy between the protagonist and the reader, as we get to experience the character's journey almost from the beginning to the end.

\section{Conclusions}

Typically for a Chicano Bildungsroman protagonist, Antonio is strongly influenced by the culture, the environment, and the harrowing experiences he faces. The process of his maturing is founded on finding a solution to multiple cultural conflicts. Tony has to deal with many reversals regarding the language barrier, the feeling of immigrant isolation and the rich diversity of Mexico's culture. Both in the school and in the family, the protagonist picks up traits of maturity. He learns to deal with the problems and becomes self-reliant. Furthermore, his identity is built by the experiences of war, violence and death. In the novel, we can undoubtedly notice how traumatic and disturbing these three elements are for Tony and how they subject the protagonist to harrowing experiences. From an innocent boy, Tony changes into a wise man. Just as much as his mother perceives the protagonist "a baby" at the beginning of the novel, she is the first to admit him to be the adult directing his family: "It was the first time I had ever spoken to my mother as a man; she nodded and obeyed" (Anaya 1972: 259). At the end of Bless Me, Ultima Antonio Juan Márez y Luna is by far a young man being undisturbed by his heritage or formidability that comes with life.

Incontrovertibly, in Rudolfo Anaya's debut novel we encounter the elements of both the Bildungsroman and the Chicano writing. It is a creation in which we observe Antonio's journey towards maturation in a Mexican-American community. The story is told from the perspective of a grown man in a first person narrative. The one that accompanies the protagonist, teaches him about his ancestors and explains the importance of historical and cultural foundations is the figure of Ultima, a mentor typical for Bildungsroman. Furthermore, the major theme of ethnic identity used by Chicano/a writers is thoroughly described in this coming of age novel. Another apparent Chicano element is the combination of Spanish and English language, which adds certain uniqueness to the story about a young Mexican American. Undoubtedly, Bless Me, Ultima is a piece allowing the readers experience the cultural introspection, for Antonio's process of maturing is founded on finding solution to social and cultural conflicts. The novel, therefore, exemplifies Chicano Bildungsroman in a uncomplicated yet remarkable manner.

\section{References}

Anaya, Rudolfo A. 1972. Bless Me, Ultima. New York, Boston: Grand Central Publishing.

Anaya, Rudolfo A. 1999. Introduction. In: Anaya R. Bless Me, Ultima. New York, Boston: Grand Central Publishing.

Bennett, Kelsey L. 2014. Principle and Propensity: Experience and Religion in the Nineteenthcentury British and American Bildungsroman. Columbia: University of South Carolina Press.

Black, Debra B. 2000. Times of Conflict: Bless Me, Ultima as a Novel of Acculturation. Bilingual Review Vol. 25 Issue 2. 146-162. 
Boes, Tobias. 2008. Apprenticeship of the Novel: The Bildungsroman and the Invention of History. Comparative Literary Studies, Vol. 45 Issue 3. 269-288.

Bolaki, Stella. 2011. Unsettling the Bildungsroman. Reading Contemporary Ethnic American Women's Fiction. Amsterdam-New York: Rodopi.

Burnett, Gary and Garry Walz. 1994. Gangs in the schools. New York: ERIC Clearinghouse on Urban Education.

Bright, William. 1976. Language and Culture. In: Bright William, Variation and Change in Language: Essays, 1-12. Stanford University Press.

Cauce, A. M. and M. Domenech-Rodríguez. 2002. Latino families: Myths and realities. In: J. M. Contreras, K. A. Kerns and A. M. Neal-Barnett (eds.), Latino children and families in the United States: Current research and future directions, 3-25. Westport, CT: Praeger.

Edelstein, Sari. 2010. Food, Cuisine, and Cultural Competency for Culinary, Hospitality, and Nutrition Professionals. Jones \& Bartlett Publishers.

Eysturoy Annie O. and José Antonio Gurpegui. 1990. Chicano Literature: Introduction and Bibliography. American Studies International Vol. 28, No. 1. 48-82.

Finer, Neal. 1979. An Instructional Model on Mexican Culture. Washington. http://www.eric. ed.gov/contentdelivery/servlet/ERICServlet?accno=ED191785.

Garasym, Tetyana. 2012. Initiation Novel VS Bildungsroman: Common and Distinct Features. НАУЧНИ ТРУДОВЕ НА РУСЕНСКИЯ УНИВЕРСИТЕТ t. 51. 183-187.

Kanoza, Theresa M. 1999. The Golden Carp and Moby Dick: Rudolfo Anaya's Multi-Culturalism. MELUS Vol. 24, Issue 2. 159-171.

Latinez, Alejandro. 2014. Developments. Encounters of Formation in the Latin American and Hispanic/Latino Bildungsroman. Peter Lang Publishing.

Ortega, Carlos F. 2012. Folk Tales. In: Herrera-Sobek M. (ed.), Celebrating Latino Folklore: An Encyclopedia of Cultural Traditions Volume 2, 548-557. ABC-Clio

Redfield, M. 2006. The Bildungsroman. In: Kastan D. S. (ed.), The Oxford Encyclopedia of British Literature Vol. 1, 191-194. Oxford University Press.

Rodriguez, Ralph E. 2010. Chicano Studies and the Need to Not Know. American Literary History Vol. 22 No. 1. 180-190.

Saracho, O. N. and F. M. Martínez-Hancock. 2005. Mexican American families: Cultural and linguistic influences. In: Saracho O. N. and B. Spodek (eds.), Contemporary perspectives on families, communities and schools Vol. VI, 203-224. Greenwich, Connecticut: Information Age Publishing.

Schmidt, Margaret. 2011. The Limitations of Code Switching in Chicano/a Literature. Young Scholars in Writing Vol. 8. 40-51.

Serrato, Philip. 2012. Ready or Not: Antonio Márez y Luna Is Thrown into the World of Rudolfo Anaya’s Bless Me, Ultima. In: Baxter, Kent (ed.), Critical Insights: Coming of Age, 228-248. Salem Press.

Sharma, Raja. 2013. Ready Reference Treatise: Bless Me, Ultima. Lulu. 